\title{
Edmund Kizik
}

\section{Gdańskie testamenty reciproce i praktyka tworzenia inwentarzy mienia w XVII-XVIII w.}

\author{
Słowa kluczowe: Gdańsk XVII-XVIII w., testamenty reciproce, inwentarze pośmiertne, \\ Luca Pacioli, rachunkowość kupiecka, księgowość podwójna \\ Key words: Gdańsk (Danzig), 17th-18th c., reciproce testaments, \\ probate inventories, Luca Pacioli, commercial book-keeping, \\ double-entry book-keeping
}

Obowiązujące w Gdańsku, podobnie jak z niewielkimi wyjątkami w pozostałych miastach Prusach Królewskich, prawo chełmińskie (ius culmense, Kulmer Recht $)^{2}$, stosunkowo dobrze zabezpieczało interesy materialne wdów, jak i wdowców na wypadek śmierci współmałżonka. Co istotne, postępowanie spadkowe w żadnym stopniu nie umniejszało roli kobiet, wdów i córek w postępowaniu spadkowym, traktując je na równi z męskimi spadkobiorcami ${ }^{3}$. Zasady alienacji majątków po zmarłych dla mniejszych miast pomorskich okresu nowożytnego omówił wyczerpująco w swojej niedawnej dysertacji Piotr Kitowski ${ }^{4}$ Dlatego też przypomnę jedynie, że włączenie za wywodzącym się z XIII w. prawem starochełmińskim ${ }^{5}$ do nowożytnych partykularnych spisów ius culmense (lidzbarska - 1566 r. $^{6}$, nowomiejska -1580 r. oraz toruńska z $1594 \mathrm{r}^{8}$ ), zasady tzw. sukcesji flamandzkiej, upowszechniło tak charakterystyczną dla nowożytnych miast Prus Królewskich małżeńską wspólnotę majątkową. Przewidywała ona, że po śmierci współmałżonka w każdym przypadku beztestamentowym (ab intestato) lub z testamentem, dzielono cały dotychczasowy majątek małżeństwa po połowie. Jedną połowę zatrzymywał w całości pozostały przy życiu małżonek (wdowa, wdowiec), z drugiej części majątku po zmarłym uposażano po równo wszystkich pozostałych, powołanych do spadkobrania.

1 Tekst niniejszy powstał w związku z przygotowywaną do druku książką E. Kizika, „Bilans na koniec życia. Gdańskie inwentarze pośmiertne od drugiej połowy XVI do początku XIX w.”.

${ }^{2}$ Według prawa magdeburskiego wdowa była wyłączona od dziedziczenia po majątku męża, zadowalając się ewentualnym wianem. Po zmarłym majątek otrzymywali zstępni, wstępni, a następnie bracia i pozostali krewni. Praktykę postępowania prawnego podsumowała Urszula Sowina (Sowina U. 2002, s. 15-28).

3 Kizik E. 2010, s. 85-98.

${ }^{4}$ Kitowski P. 2015, s. 55-57.

5 Prawo starochełmińskie. 1985.

${ }^{6}$ Jus Culmense Correctum. 1711. Tłum. polskie na podstawie szesnastowiecznego rękopisu z Archiwum Państwowego w Gdańsku oraz wydania drukowanego z 1711 r. Dzieło J. Kunigka wydał Andrzej Groth, zob.: Rewizja lidzbarska. 1993.

${ }^{7}$ Rewizja nowomiejska. 1993. W części miast pruskich na południu prowincji posługiwano się opublikowanym tłumaczeniem na język polski: Kuszewic P. 1623; zob.: Sondel J. 1994, s. 263-289.

8 Tekst prawa opublikowany wraz z komentarzem w: Hanow M.Ch. 1745/1767. 
Jednak, jak wynika z moich studiów nad pośmiertnymi testamentami i inwentarzami gdańskimi z XVII i XVIII w., małżonkowie, szczególnie z zamożniejszych warstw mieszczańskich, najczęściej korzystali ze spadkobrania w oparciu o rozporządzenie testamentowe. Umożliwiało to zwiększenie części spadku przypadającego wdowie (lub wdowcowi), wskazanemu spadkobiercy, ewentualnie wydzielenie legatu na cele społeczne ${ }^{9}$. Raczej do rzadkości należą przypadki, w których nie korzystano z tej prawnej możliwości wpływania na pośmiertne losy własnego majątku. Ograniczenia, czyli dziedziczenie beztestamentowe, dotyczyło przede wszystkim ubogich mieszkańców, których nie było stać zarówno na opłacenie kosztów sporządzenia stosunkowo kosztownego dokumentu, jak i na uiszczenie obligatoryjnego podatku W wysokości 10 grzywien na utrzymanie dróg i kładek ${ }^{10}$. Testatorów zobowiązywał do tego wilkierz miejski ${ }^{11}$. Niemałe były również koszty dodatkowe, albowiem opłata za testament sporządzony w obecności ławnika na początku XVIII w. wynosiła 48 fl. i 14 gr (tyle wyłożono np. za spisany w mieście testament biskupa warmińskiego, Michał Augustyna Radziejowskiego w 1705 r. $)^{12}$. Za testament sporządzony w sądzie należało wyłożyć 13 fl. i 12 gr, a oświadczenie ostatniej woli w domu testatora (der gemeinste Modus zu testiren) ${ }^{13}$, w obecności dwóch świadków oraz pisarza sądowego, kosztowało $18 \mathrm{fl}$. $16 \mathrm{gr}^{14}$. Za testament wspólny (testamentum reciprocum) o formule standardowej małżonkowie płacili 18 fl. i 6 gr. Jeśli w treści dokumentu miały być uwzględnione dodatkowe życzenia, legaty, wyłączenia itp., to opłata ulegała podwojeniu - do 36 fl. i 12 gr $^{15}$.

Istniejący przymus zawierania małżeństw przez obywateli w przeciągu roku od otrzymania praw miejskich oraz członków cechów ${ }^{16}$ również przyczyniał się do upowszechnienia w środowiskach zamożniejszych mieszczan właśnie testamentów reciproce ${ }^{17}$. Zawierały one wspólne oświadczenie woli obydwojga małżonków, którzy na wypadek śmierci jednego z nich zapisywali sobie wzajemnie do trzech czwartych z przypadającej im „,połowy chełmińskiej”"18. Była to maksymalna, dopuszczalna prawem suma zapisu. Osiemnastowieczny uczony gdański,

9 Podstawowy zarys obowiązującego w Gdańsku prawa spadkowego opracował w 1576 r. sekretarz Rady Miejskiej Gdańska, Kaspar Schütz. Podobnie jak wiele opracowań prawno-historycznych z powodu cenzury władz miejskich dzieło funkcjonowało w wielu odpisach (Schütz Kaspar. 1576; Katalog. 1892). Dzieło Schütza znajdowało się również w prywatnych bibliotekach gdańszczan, o czym świadczy wzmianka (Caspar Schutzii Process von Erbfällen) w pośmiertnym inwentarzu Paula Wildego z 1679 r., AP Gdańsk, sygn. 300, 1/335, s. 31.

${ }_{10}$ Neu-revidirte Willkühr. 1761, s. 104 (rozdz. 6, art. 10): Wer testiren will, muß 10 Marck gering zu Wege und Stege bezahlen. Zob. też: Erörterte successions. 1732, s. 42; wcześniejsze wersje tego szczegółowego wykładu prawa spadowego w Gdańsku w: Bibl. Gd. PAN, Ms 347, Ms 348 (z lat 1727 i 1728).

11 W badanym okresie w Gdańsku obowiązywały wilkierze z 1597 i 1761 r.: Der Stadt Dantzigk Willkühren. 1597. Tekst starego wielkierza z 1597 r. został opublikowany bez aprobaty Rady Miejskiej oraz bez późniejszych zmian w niepodlegającej jurysdykcji miejskiej drukarni we Wrzeszczu, zob.: Der See- und Handels-Stadt Danztig. 1732. W 1761 r. uchwalono i opublikowano drukiem nowy wilkierz: Neu-revidirte Willkühr. 1761 (wydanie drugie: Danzig. 1783). Omówienie zawartości wilkierzy w: Simson P. 1904; Maciejewski T. 1989, s. 49-70.

12 Przykłady przytoczone w: Erörterte successions. 1727, s. 35.

13 Erörterte successions. 1727, s. 32-33, 35.

14 Erörterte successions. 1727, s. 32-33.

15 Erörterte successions. 1727, s. 43.

16 Mężczyźni po otrzymaniu obywatelstwa byli zobowiązani, by w przeciągu roku zawrzeć związek małżeński. Osoby, które bez wiarygodnego usprawiedliwienia pozostawały w stanie kawalerskim karano grzywnami, zob.: Kizik E. 2009, s. 147-155.

17 Były one przedmiotem osiemnastowiecznych komentarzy prawniczych: Becker J.G. [ok. 1750], k. 2v-20v.

18 Np. w testamencie spisanym 17 grudnia 1767 r. sławnego muzyka gdańskiego, Georga Simona Löhlein i jego żony Elisabeth z domu Piper. Małżonkowie zapisali sobie wzajemnie po 3/4 majątku z przypadających im połówek chełmińskich (3/4 Part aus ihrer Culmischen Helffte legiret hat). Zob. inwentarz Löhleina zmarłego 16 grudnia 1781 r., AP Gdańsk, 300, 5/193e, s. 71-81. Porównawcze omówienie kwestii majątkowych w środowiskach mieszczan warszawskich: Ehrenkreutz S. 1915; Sowina U. 2002, s. 15-28. 
Michael Christoph Hanow, w komentarzu do Ius culmense (ks. 3, tyt. 8, art. 16 art.) thumaczył, że: nach der heutigen Praxis kann keiner in Danzig über 3/4 Part vermachen, sondern muß 1/4 Part entweder seinen Brüdern, Verwandten oder dem Fisco lassen ${ }^{19}$.

Obowiązek wydzielenia część obowiązkowej, czyli zachowka (w źródłach jako Pflichteil), funkcjonował w Gdańsku już w XVI w., lecz został potwierdzony decyzjami Ordynków w 1613 i 1616 r. Odtąd gdańscy testatorzy nie zapisywali już nigdy więcej ponad 3/4 majątku, którym dysponowali ${ }^{20}$. Mogli jednak zapisywać mniej. Na przykład w testamencie Benjamina Seemana i jego żony Ewy Grubin (1729 r.) mąż zapisał żonie 3/4 swojego majątku, zaś żona mężowi tylko 1/4. Resztą uposażyła swoje dzieci z pierwszego małżeństwa. Jednak zaznaczono, że gdyby dzieci bezpotomnie zmarły przed nią, to wdowiec otrzyma 3/4 części ${ }^{21}$. Wedle wskazanej wyżej proporcji nastąpił np. podział skromnego majątku po Michaelu Schönbergu, robotniku zmarłym w 1787 r. na gdańskich Długich Ogrodach ${ }^{22}$. Wdowa odziedziczyła 7/8 wspólnego majątku, czyli swoją połowę chełmińską oraz zapisane $3 / 4$ z połowy męża - nieboszczyka. Ponieważ małżeństwo było bezdzietne, to pozostałą 1/8 (część obowiązkowa) zajął fiscus, czyli miasto Gdańsk. Podobnym zapisem testamentowym zabezpieczona została Eva Maria Gellentin, zatrzymując po śmierci męża 1711 fl. i 15 gr. Resztę sumy, czyli ósmą część w wysokości 122 fl. 7 i $1 / 2$ gr, otrzymali do podziału bracia przyrodni zmarłego, Johann M. Dombrowski i Johann D. Dombrowski²3.

Odpowiednie zabezpieczenie majątkowe współmałżonka powodowało drastyczne pomniejszenie części przeznaczonej dla pozostałych dziedziców, albowiem połowa chełmińska wraz z maksymalnie prawnie dopuszczoną częścią zapisu majątkowego (3/4 z połowy testatora), którą wolno było zapisać dziedzicowi, stanowiła w sumie 7/8 wartości całego majątku współmałżonków. Inni powołani do spadkobrania mieli do podziału zaledwie ósmą część wspólnej majętności małżonków, co niekiedy było już stosunkowo niewielką sumą. W razie nieobecności spadkobierców, w ich imieniu obowiązkową część zabezpieczało miasto. To również w interesie finansów miasta wprowadzono zapis o części, która nie podlegała zapisowi wzajemnemu, a pozostawała do dyspozycji dziedziców.

Gdańsk był miastem królewskim i spadki bezdziedziczne jako kaduk przepadały ostatecznie na rzecz króla. Sprawy w jego imieniu kontrolował i rozliczał Urząd Burgrabiego ${ }^{24}$. Jednak miasto, również ze względów fiskalnych, zabiegało o przejęcie pełnej kontroli zarówno nad samym postępowaniem spadkowym, jak i nad bezdziedzicznym dobrem. Dlatego po wieloletnim dzierżawieniu kaduków w 1660 r. doszło ostatecznie do wykupienia ich od króla Jana Kazimierza $^{25}$. Od tej pory jedynie kaduki o wartości przewyższającej 50000 guldenów, podobnie jak majątki zdrajców i banitów, przechodziły na rzecz władcy. Oszacowanie ostatecznej wartości takich majątków stawało się przedmiotem zażartych kontrowersji pomiędzy stronami zainteresowanymi w przejęciu majątku, czyli Radą Miejską a dworem.

W kręgach osób bardzo zamożnych niejednokrotnie zdarzało się, że mimo sporządzenia ważnego testamentu, z uwagi na zapisy niekorzystne dla statutowych dziedziców, nie ujawniano istnienia dokumentu, ewentualnie starano się nie dopuścić do jego otwarcia i ogłoszenia woli zmarłego (zmarłej). Naturalnie działo się to wtedy, gdy skądinąd wiedziano lub podej-

19 Hanow M.Ch. 1745/1767, s. 126, przyp. 66.

20 Postanowienia dotyczące wielkości części obowiązkowej zostały włączone do wilkierza na podstawie postanowień ordynków z 23 maja 1613 i 22 lipca 1616 r., Erörterte successions. 1727, s. 216; Simson P. 1904, s. $127-128$.

${ }^{21}$ AP Gdańsk, sygn. 300, 5/158, s. 110-111.

22 AP Gdańsk, sygn. 300, 1/168, s. 853 n.

${ }^{23}$ AP Gdańsk, sygn. 300, 1/168, s. 941.

${ }^{24}$ Przykłady rozliczenia kaduków gdańskich z pierwszej połowy XVII w., zob.: AP Gdańsk, sygn. 300, $3 / 43$.

${ }^{25}$ Odpis przywileju, zob.: Erörterte successions. 1727, s. 213-214; por.: Kizik E. 2004, s. 5-14. 
rzewano, że testator dokonał nadzwyczajnych zapisów na cele publiczne lub dla osób niespokrewnionych, ewentualnie nieuprawnionych do dziedziczenia statutowego, co dotkliwie naruszało interesy członków rodziny. Tak jak na wstępnie podkreślono, kobiet testatorek nie obowiązywały w tym zakresie żadne rozporządzenia, które ograniczałyby ich pozycję prawną w porównaniu z mężczyznami.

Praktyka nieotwierania testamentów zamożnych gdańszczan z legatami na cele dobroczynne była na tyle częsta, że w pierwszej połowie XVIII w. stała się przedmiotem publicznej dyskusji. Doprowadziło to do ataków pospólstwa reprezentowanego przez Trzeci Ordynek na Radę Miasta i ostatecznie trafiło na listę pretekstów uzasadniających interwencję króla Augusta III w wewnętrzne ustawodawstwo Gdańska w latach 1749-1751. Rada Miejska pod naciskiem dworu zdecydowała o otworzeniu przechowywanych w depozytach testamentów z lat 1650 $-1720^{26}$ oraz o podawaniu do wiadomości publicznej treści zapisów dobroczynnych ${ }^{27}$. Z ujawnianych zestawień wynika jasno, że zapisy na te cele niejednokrotnie dotyczyły niebagatelnych kwot, dochodzących do dziesiątek tysięcy guldenów ${ }^{28}$. Na przykład Nathanael Kohl, w testamencie otwartym 4 lutego 1780 r. przeznaczył 30 tysięcy fl. na kapitał założycielski fundacji dla wdów powierzonych opiece pastora i zarządu kościoła Mariackiego w Gdańsku ${ }^{29}$. W tym samym testamencie na rzecz Lazaretu zapisano 20 tysięcy, Sierociniec otrzymał 4 tysiące oraz Dom Dobroczynności - 6 tysięcy fl. Legat w wysokości 200 tysięcy fl. na rzecz wdów oraz biednych panien wyznania reformowanego zapisała w testamencie wdowa po Wilhelmie Jakobie Paleske z domu Dickhoff (testament ogłoszono 19 czerwca 1780 r.) ${ }^{30}$. Natomiast 10 tysięcy fl. na utrzymanie 10 biednych wdów po pastorach przeznaczyła w swoim testamencie Dorothea Agatha Schuman, zmarła 22 kwietnia $1782 \mathrm{r}^{31}$

Powróćmy do tytułowego zagadnienia testamentów wzajemnych. Testamenty reciproce były najczęściej sporządzane dość szybko po zawarciu związku małżeńskiego, np. w okresie zaawansowanej ciąży kobiety i obawy przed nadchodzącym porodem. Bliski związek czasowy pomiędzy spisaniem testamentu wzajemnego a zawarciem małżeństwa prowadził niekiedy do utożsamiania tego instrumentu prawnego z kontraktem małżeńskim. Jeśli takich testamentów nie spisano wraz ze ślubem, to następowało to na długo przed śmiercią, gdy małżonkowie nie znali jeszcze stanu swego przyszłego majątku. Dlatego też w treściach aktów ostatniej woli $\mathrm{z}$ reguły nie posługiwano się konkretnymi sumami, nie wymieniano konkretnych przedmiotów, lecz operowano jedynie częściami udziału w masie spadkowej przynależnej wskazanym dziedzicom. Konkretną wartość części spadkowych, również części obowiązkowej, szacowano i wyliczano na podstawie inwentarza całego wspólnego majątku, który spisywano po śmierci jednego z małżonków. Ostatecznie wartość netto całego majątku można było ustalić w drodze publicznej licytacji dóbr po zmarłym.

Zasady dziedziczenia testamentowego według prawa chełmińskiego znacząco wzmacniały pozycję materialną i społeczną kobiet w Gdańsku. W razie zapisu wzajemnego, wdowy po mistrzach cechowych były głównymi spadkobierczyniami majątku głównego, zaspokajając

${ }^{26}$ Na problem zwrócił uwagę Cieślak E. 1972, s. 148; zob.: Löschin G. 1837, s. 39-41.

${ }_{27} \mathrm{~W}$ ostatniej ćwierci XVIII w. informacje o uposażeniach testamentowych w Gdańsku publikowano obszernie na łamach miejscowej gazety rękopiśmiennej, zob.: Kizik E. 2015, s. 129-144.

28 Zasady testamentowych zapisów stypendialnych, zob.: Kotarski E. 2000, s. 114-120, 126-128. Uwagi Z. Kropidłowskiego nie poszerzają wiedzy na ten temat (Kropidłowski Z. 1992, s. 161-165). Mimo zmian religijnych związanych z reformacją, a następnie polityczno-prawnych w okresie pruskim w XIX w., gdańskie fundacje założone w XV-XVIII w. przetrwały niejednokrotnie do XX w. Wykaz fundacji gdańskich wraz z wkładami w przeliczeniu na współczesną walutę, zob.: Verzeichnis. 1903.

29 Rubachs Monathliche Sammlung. [1780-1782] (bez paginacji, wpisy w układzie chronologicznym).

30 Rubachs Monathliche Sammlung. [1780-1782].

31 Rubachs Monathliche Sammlung. [1780-1782]. 
jedynie roszczenia pozostałych dziedziców. Mimo narzuconych ograniczeń w cechowej działalności gospodarczej kobiet, korzystająca z pomocy kuratora wdowa zachowywała niepodważalne prawo do większości majątku, a jej przewaga materialna nad synami była bezsporna ${ }^{32}$. Wiele kobiet, mimo prawnych nacisków, nie zawierało nowych związków małżeńskich, co oznaczało automatyczne przejście pod kuratelę męża i utratę kontroli nad majątkiem. Niekiedy doskonale odnajdywały się w nowych rolach życiowych. Na przykład Catharina, wdowa po sławnym gdańskim ludwisarzu Michaelu Wittwercku, prowadziła samodzielnie warsztat. Podpisywała umowy na wykonanie dzwonów (np. w 1744 r.) ${ }^{33}$, kontrolowała przebieg prac, a jej syn Emanuel, mimo nabycia w 1742 r. uprawnień mistrzowskich, za życia matki nie został właścicielem przedsiębiorstwa ${ }^{34}$.

Formuła testamentu reciproce powtarzana była w dziesiątkach i setkach dokumentów bez znaczących różnic, przez cały badany okres. Była na tyle popularna, że w drugiej połowie XVIII w. pojawiły się nawet druki akcydensowe z odpowiednimi formularzami testamentowy$\mathrm{mi}^{35}$. W odpowiednich miejscach wpisywano nazwiska testatorów, ewentualnie uzupełniano treść kwestionariuszy o niestandardowe zapisy szczegółowe.

W praktyce spadkowej dużego miasta handlowego, w której powszechnie operowano ułamkami majątku podlegającemu spadkobraniu, a testamenty szybko przestały pełnić dodatkową rolę spisów przekazywanych rzeczy ${ }^{36}$, niezwykle istotną rolę przypisywano umiejętnemu i powszechnie akceptowanemu sposobowi prowadzącemu do prawidłowego wyliczenia wartości masy spadkowej ${ }^{37}$. Dlatego podstawowym narzędziem, umożliwiającym właściwe i akceptowalne społecznie ujawnienie oraz ustalenie kwot należnych do podziału, stał się w XVI w. odpowiednio sporządzony pośmiertny inwentarz mienia. Tylko na podstawie takiego narzędzia księgowonotarialnego można było w sposób precyzyjny i rzeczowy ustalić rzeczywistą masę spadkową brutto, a następnie wyliczyć jej wartość netto, wraz z określeniem sumy działów należnych spadkobiercom, ewentualnie fiskusowi. Pomijam kwestię recypowanego z prawa rzymskiego dobrodziejstwa inwentarza, czyli zabezpieczenia głównego sukcesora przed przeniesieniem nań ciążących na spadku zobowiązań, co było konsekwencją połączenia majątku dziedziczonego $\mathrm{z}$ majątkiem własnym dziedzica. W dużych ośrodkach miejskich, $\mathrm{z}$ uwagi na rozległość prowadzonych interesów handlowych oraz rozliczeń dokonywanych niekiedy i po wielu miesiącach, przejęcie majątku bez jego dostatecznego rozpoznania byłoby bardzo ryzykowne.

Przechodząc do kwestii genezy standardowego formularza inwentarzowego, rozpocznę od przytoczenia treści pewnej inskrypcji epitafijnej. Na kamieniu nagrobnym wmurowanym w mur okalający cmentarz przy kościele Mariackim w Elblągu (w okresie nowożytnym głównej świątyni luterańskiej miasta) znajduje się znamienny tekst epitafium poświęconego pewnemu kupcowi, bliżej nieznanemu Martinowi Schmidtowi (zmarłemu w 1705 r.). Sam zabytek jest już mocno zniszczony, dlatego podaję transkrypcję epitafium spisaną przez zbieraczy elbląskich starożytności ${ }^{38}$, wraz z odwzorowaniem formalnego układu inskrypcji (ryc. 1).

32 Przykłady cytowane w: Bogucka M. 1962, s. 384-386; por.: Tuchołka-Włodarska B. 1985, s. 103-113; Binerowski Z. 1963, s. 196.

33 Neue Kirchenglocke in Schönbaum. [1744], s. 1-3.

34 Zob.: Kizik E. 2003, 3-4, s. 405-414.

35 Dziesiątki testamentów spisanych na drukach akcydensowych ingrosowano do księgi ławniczej Starego Miasta Gdańska w latach siedemdziesiątych XVIII w., AP Gdańsk, sygn. 300, 43/172.

36 Taka rolę pełniły testamenty średniowieczne; zob.: dla Gdańska - Możejko B. 2004, s. 127-162; dla Elbląga — Kubicki R. 2010, s. 199-213; Kubicki R. 2018, s. 37-50.

37 Przykładowe wyliczenia dla różnorodnych spadkobiorców: Erörteterte successions. 1727. Również w gdańskich podręcznikach rachunkowych przeprowadzono ćwiczenia na wyliczenie działów spadkowych, Sartorius W. 1592, [k.] 139v (nr 11-16).

38 Odpis inskrypcji podają: Neumann J.G. [b.d.], k. 252 b (490b); Dewitz J.H.; por.: Fuchs M.G., Bd. 2, s. 338; Döring G. 1846, s. 44-51 (epitafia). 


\section{Wahrer Christen Handel}

DeBeT

Alle Welt ist Gott schuldig

Darumb das kein Fleisch

Durch des Gesetzes Werck

Vor ihm gerecht ist
CREDit

Christus ist uns gemachet worden Von Gott zur Weißhelt und zur Gerechtigkeit und zur Heiligung und zur Erlösung

Christus ist des Gesetzes Ende, wer an den glaubet, der ist gerecht

Diese Rühestätt

Hat sich und seinen Erben ersehen

\section{MARTIN SCHMIDT \\ Anno 1705}

Ich war ein Handels Mann der mit den Theuren Waaren auff ein gebrechlich Holtz durch großen Sturm gefahren Der Schiff Mann, die Vernunft das Wilde Meer die Welt Der Schwache Leib das Schiff der Haaff ein Todten Feld Der Himmel war das Ziehl der gantzen weiten Reise Die Wahr der Seelen Schatz nach Kauffmanns Art und Weyse Nun ist der Haaffen mein die Wahr zu recht gebracht Glück zu mein Vaterland hab' Welt, hab` gutte Nacht

Christus

ist mein Leben

Sterben

ist mein Gewin

Ryc. 1. Epitafium kupca Martina Schmidta (†1705) przy kościele Mariackim w Elblągu

Fig. 1. The epitaph of the merchant Martin Schmidt (†1705) at St Mary’s church in Elbląg (Elbing)

Tekst epitafium nie tylko stanowi nawiązanie do zawodu nieboszczyka (Ich war ein Handels Mann der mit den Theuren Waaren auff ein gebrechlich Holtz durch großen Sturm gefahren), ale również jest graficznym odwzorowaniem buchalteryjnego zapisu salda: Debet et Credit, czyli Soll - Soll haben, Winien - Ma). Po „zsumowaniu” słupków, które z księgowego punktu widzenia stanowią przeniesienie sald końcowych do bilansu zamknięcia, czytelnik otrzymuje fundamentalny wykład wiary w odkupienie win przez Jezusa Chrystusa. Jest to logiczna konsekwencja zapisu na nagrobku. Nie są to jednak, moim zadaniem, rozważania teologiczne, lecz skupienie się na kwestii związków pomiędzy zacytowaną inskrypcją a inwentarzem pośmiertnym, czyli księgowym zapisem Debet - Credit. 
Nie odnalazłem inwentarza pośmiertnego Schmidta. Wartość majątku zamożnego mieszczanina z Elbląga z całą pewnością została wyliczona tak samo banalnie, jak w przypadku zmarłej w maju 1773 r. gdańskiej mieszczki, Catharinie Protman ${ }^{39}$, mieszkającej kątem u Johanna Jocoba Bartscha. Ruchomości zestawione w inwentarzu (w źródle na karcie 3) zostały wycenione ogółem na 307 fl.; z listy długów spisanych na karcie 4 wynika, że gospodarzowi Bartschowi należało się $301 \mathrm{fl}$. za piwo oraz z tytułu półrocznego czynszu. Po potrąceniu roszczeń wartość netto majątku wyniosła raptem 6 fl., którymi mieli podzielić się po równo spadkobiercy i fiskus. Testamentu nie sporządzono, jego spisanie oraz konsekwencje podatkowe przekroczyłyby wartość majątku. Dlatego po połowę spadku sięgnął Urząd Kaduków, zaś drugą część zatrzymano w depozycie, w oczekiwaniu na ewentualnego spadkobiorcę. Zapis, przynajmniej jeśli chodzi o układ graficzny karty, sporządzono identycznie jak tekst z rzeczonego odrysu epitafium oraz różnorakich kart bilansowych.

Podstawą stworzenia bilansu był prawidłowy inwentarz — Das Inventarium ist das Caput und Fundament der Rechnung, jak pisał norymberski notariusz, Adam Volckmann, w wielce popularnym i wielokrotnie wznawianym podręczniku sztuki notarialnej (Notariat Kunst) opublikowanym po raz pierwszy w latach $1621-1622^{40}$. Historycy poszukujący genezy inwentarza majątkowego nie bez racji nawiązują do wzorców i wskazówek zamieszczonych właśnie w nowożytnych pomocach notarialnych ${ }^{41}$. Najbardziej reprezentatywne dla tego kierunku są w Niemczech studia Hildegard Mannheims ${ }^{42}$, w Polsce zaś Andrzeja Klondera ${ }^{43}$. Bez wątpienia tego rodzaju podręczniki odegrały istotną rolą $\mathrm{w}$ utrwalaniu zasad postępowania inwentaryzacyjnego oraz tworzenia standardowego zapisu dokumentu. Nie lekceważę tego rodzaju poradników, szczególnie, że wznowienia tych dzieł potwierdzają ich ponadprzeciętną popularnośćc ${ }^{44}$. Nie wyjaśniają one jednak genezy charakterystycznego układu, według którego tworzono takie wykazy, pochodzenia ich cech formalnych, jak i powszechności ich stosowania na całym obszarze Europy Łacińskiej.

O ile wspomniani badacze koncentrowali się na rozwoju notariatu publicznego, o tyle wydaje się, że genezy inwentarza należy upatrywać raczej w rozwoju księgowości kupieckiej. Moja teza jest następująca: powszechna umiejętność oraz podobieństwa formalne inwentarzy pośmiertnych pochodzących z różnych regionów Europy są efektem recepcji późnośredniowiecznych, włoskich technik sporządzania dokumentacji rachunkowej przedsiębiorstw oraz umiejętności opracowania okresowego bilansu handlowego. Dążenie do stworzenia przejrzystej dokumentacji rachunkowej prowadziło z czasem do przekształcenia ksiąg pojedynczych w podwójne, w których każdy zapis na jednym koncie ma swój odpowiednik na innym koncie. Taki system umożliwiał zarówno bieżącą ewidencję kosztów i dochodów, bilansowanie wszystkich zapisów debetowych i kredytowych wniesionych na poszczególne konta, jak również możliwość sporządzania bilansu końcowego jako zestawienia sald wszystkich prowadzonych kont ${ }^{45}$. W nawiązaniu do treści cytowanego elbląskiego epitafium z 1705 r. warto pamiętać, że dla człowieka momentem obrachunku jest kres życia, czyli śmierć.

W niniejszym artykule pomijam zagadnienie rozwoju późnośredniowiecznej rachunkowości. Jedynie za obfitą literaturą przedmiotu wspomnę, że wedle zasad podwójnej buchalterii

39 AP Gdańsk, sygn. 300, 1/340, s. 39-45.

40 Dzieło doczekało się wielu wydań w XVII i XVIII w., zob.: Bibliographie. 2007, s. 363-365, nr 1358-1359. Korzystałem z: Volckmann A. 1654, s. 118-119.

${ }^{41}$ Z uwagi na przynależność Gdańska wraz z całymi Prusami Królewskimi do niemieckiej tradycji prawnej i notarialnej pożytecznym jest przegląd tamtejszych dzieł publikowanych w XVI-XVII w., Bibliographie 2007. Alfabetyczne a nie chronologiczne ujęcie bibliografii utrudnia wykorzystanie zbioru.

42 Mannheims H. 1991.

43 Klonder A. 2000, s. 7-9, 16-19.

44 Bibliographie. 2007

45 Początki tworzenia bilansu w rachunkowości kupieckiej, zob.: Penndorf B. 1913, s. 62-67. 
były prowadzone genueńskie księgi kupca Massariego z 1340 r. ${ }^{46}$ Umiejętności przygotowania inwentarzy mienia wraz z szacunkami wartości są czytelne w obfitej spuściźnie księgowej po

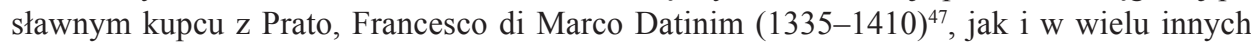
źródłach z epoki ${ }^{48}$. Tyle średniowieczna praktyka kupiecka. Dla upowszechnienia się tej metody i wyjścia poza krąg włoskich przedsiębiorców istotny był jednak moment spisania oraz usystematyzowania tej wiedzy. Dokonał tego u schyłku XV w. Luca Pacioli de Burgo (1445-1514?), franciszkanin i profesor matematyki, przyjaciel Leonarda da Vinci oraz Leona Battisti Albertiego. Fra Pacioli wydał drukiem w 1494 r. pracę w języku włoskim, lecz pod łacińskim tytułem: Summa de Arithmetica, Geometrica, Proportioni et Proportionalita. W traktacie XI, rozdziału 9 części III (Tractatus XI. Particularis de computis et scripturis) ${ }^{49}$ autor zebrał, usystematyzował, a następnie precyzyjnie omówił zasady księgowania wypracowane przez miejscowych kupców od XIV stulecia. Opisał także wenecki sposób sporządzania inwentarza oraz prowadzenia podstawowych ksiąg rachunkowych — dziennika, memoriału oraz księgi głównej wraz z charakterystyką dokonywania zapisów. Przedstawił również rachunek strat i zysków oraz bilans wszystkich kont — zaczątek przyszłego bilansu majątkowego. A wszystko to, aby zapobiec zamieszaniu. Jak to przysłowiowo oddaje Pacioli: Ubi non est ordo, ibi est confusio. W rozdziałach drugim (De la prima parte principale de Questo tractato, detta inventario, e che cosa sia inventario, e comme fra mercatanti s'abi a fare) oraz trzecim (Forma exemplare con tutte sue solennita in lo inventario requisite) uwzględnione jest zagadnienie najbardziej frapujące z niniejszego punktu widzenia, czyli inwentarz mienia i sposoby jego wykonania ${ }^{50}$. Według uczonego franciszkanina, kupiec musiał spisać go na oddzielnej karcie lub w księdze. Spis ruchomości i nieruchomości powinien rozpoczynać się od przedmiotów, które są najbardziej kosztowne i można je łatwo zbyć, czyli poza samą gotówką, przede wszystkim z metali szlachetnych. Dopiero w dalszej kolejności należy spisać nieruchomości, takie jak domy, pola, stawy rybne, albowiem - jak uważał Fra Pacioli — te ostatnie nie ulegają tak łatwemu zatraceniu jak pieniądze i kruszce. Uczony franciszkanin poszedł dalej w swoich rozważaniach i zaproponował czytelnikowi praktyczny formularz sporządzania wzorowego inwentarza. Poczynając od tytułu, daty, miejsca, poprzez wszystkie składniki majątkowe (mobili e stabili), jak również długi oraz wierzytelności — debiti e crediti. Następnie w punktach zalecił odnotować pozycje składające się na majętność kupca:

Po pierwsze: całą posiadaną gotówkę, w złocie i innych kruszcach, z wyszczególnieniem liczby dukatów weneckich, węgierskich, papieskich, sieneńskich i florentyńskich. Potem należy wymienić resztę gotówki w srebrnych i miedzianych monetach różnych emisji oraz z różnych państw (lirów, florenów, groszy).

Po drugie: liczbę posiadanych kamieni szlachetnych (diamentów, rubinów, szafirów) zarówno oprawionych, jak i luzem wraz z opisem szlifów; następnie pierścienie wraz z określeniem wagi klejnotów w uncjach, karatach i granach (bliższe opisy pozostawił Paccioli uznaniu spisującego - narrando le sorti e pesi a tua voglia).

46 Penndorf B. 1933, s. 1-2.

47 Penndorf B. 1933, s. 36-37.

${ }^{48}$ Accounting history. 1996, s. 11-12; Peragallo E. 1938, s. 3-17 (przykłady z ksiąg komun miejskich w Genui i Florencji).

${ }^{49}$ Pacioli L. 1994. Tekst traktatu został upowszechniony w badaniach historycznych dzięki niemieckiemu thumaczeniu Balduina Penndorfa, który włączył je do swojej pracy na temat księgowości włoskiej (Penndorf B. 1933). Polskie thumaczenie z włoskiej podstawy ukazało się w 2007 r. (zob.: Pacioli, L. Tractatus XI. 2007); wcześniejsze tłumaczenie za B. Penndorfem opublikował Scheffs M. 1939. Zarys problematyki zob.: Turzyński M. 2016, s. 271-285.

${ }^{50}$ Pacioli L. 1994, s. 59. 
Po trzecie: ubrania, z podaniem liczby poszczególnych rodzajów odzieży, z zaznaczeniem jakości materiału, koloru, podbicia, podszewki oraz ich kształtu.

Po czwarte: wyroby srebrne, takie jak kubki, miski, następnie zastawa kuchenna miedziana, łyżki i widelce. Również i w tym przypadku spisujący powinien zwrócić uwagę na opisanie wszystkich kategorii ([...] tutto le sorti a una per una) wraz z dokonaniem podziału na odpowiednie grupy. Następnie przedmioty powinny zostać przeliczone i zważone. Gdy to możliwe, zalecano określenie pochodzenia danego przedmiotu (Paccioli rozróżniał robotę wenecką i raguską, czyli z Dubrownika) oraz zwrócenie uwagi i podanie w miarę możliwości cech probierczych wybitych na naczyniach.

Po piąte: bieliznę znajdującą się w gospodarstwie domowym, z podziałem na stołową i przeznaczona do spania, koszule, ręczniki, itd. (oraz ich liczba). Autor informował, że prześcieradła mogą mieć różną długość (np. trzy długości i 2 1/2 długości), dlatego należy określić ich wielkość i proweniencję (czy są wyrobami płóciennymi z Padwy, czy z innego miasta), stan ich zachowania (novi, usati) oraz rodzaj materiału.

Po szóste: pierzyny i poduszki wraz z poszwami (ponownie ze wskazaniem jakości novi, usati) oraz ich wagi.

Po siódme i ósme: towary korzenne, np. liczba skrzyń z imbirem ,z Mekki”, pieprzu, cynamonu, goździków, bazylii, drzewa sandałowego wraz z ich wagą, liczbą opakowań.

Po dziewiąte i dziesiąte: futra krajowe oraz zagraniczne wraz z dokładną ich liczbą i opisem.

Po jedenaste: nieruchomości z adresem i opisem domu (liczba pięter, pomieszczeń, podwórek, studni, ogrodu), ze wskazaniem prawnych podstaw własności.

Po dwunaste: nieruchomości wiejskie — ziemia rolna z odpowiednim inwentarzem; opis prawnych podstaw własności oraz bieżący sposób użytkowania (np. dzierżawa), jak również roczny zysk oraz długi, prawa i służebności obciążające posesję.

Po trzynaste: dzierżawione skrypty dłużne i zastawy; ich wartość, zyski, terminy płatności.

Po czternaste: posiadane wierzytelności, lista dłużników, wysokość oraz rodzaj udzielonych pożyczek, podstawy rozliczenia, terminy spłat oraz warunki, na jakich zostały udzielone; sposób udokumentowania zobowiązań.

Po piętnaste: długi obciążające majątek. Podobnie jak w przypadku wierzytelności istotne było wskazanie warunków ich spłat, ich wysokości itp. ${ }^{51}$

Dzieło Paciolego jest sumą wiedzy wypracowywaną przez włoskich kupców od XIII w., a znaczenie tej pracy polega na stworzeniu standardu — stosunkowo prostej i logicznej propozycji ujednolicenia metod księgowania, które w praktyce stosowano od dziesięcioleci w domach kupieckich miast weneckich i innych. Pacioli przy tym konsekwentnie operował liczbami arabskimi, a nie rzymskimi, niezwykle utrudniającymi praktyczną rachunkowość. Zacytowany, usystematyzowany przez niego spis majątku w układzie rzeczowym, jest charakterystyczną cechą większości nowożytnych inwentarzy pośmiertnych. W inwentarzach gdańskich mieszczan posesjonatów zawsze na pierwszym miejscu wykazywano nieruchomości wraz z ich wartością określoną na podstawie transakcji zakupu, a także odpowiedni odnośnik do księgi gruntowej. Potem dopiero wymieniano gotówkę oraz wyroby z kruszców, metali nieszlachetnych, ubrania, bieliznę, ceramikę kuchenną, towary, wyposażenie warsztatów itd. Od XVII w. coraz powszechniej jako osobną kategorię odnotowywano książki.

Samo dzieło Paciolego doczekało się jeszcze kilku wydań w XVI stuleciu ${ }^{52}$, a dzięki rozwojowi drukarstwa jego koncepcja została przejęta przez licznych kupców, praktyków-matematyków, nauczycieli rachunkowości, którzy adoptowali je do miejscowych warunków. Nowe

${ }^{51}$ Na podstawie Pacioli L. 1994, s. 59-62, niemieckie thumaczenie w: Penndorf B. 1933, s. 90-94, polskie tłumaczenie w: Scheffs M. 1939.

52 Sangster A. 2007, s. 125-145. 
techniki księgowania były prezentowane w szesnastowiecznych pracach autorów włoskich, takich jak Girolamo Cardano (Practica Arithmeticae et Mensurandi singularis, 1539) ${ }^{53}$, niderlandzkich — Jana Ympyna (Nieuwe Instructie, 1543) ${ }^{54}$, Davida Kocka ${ }^{55}$, jak również autorów angielskich ${ }^{56}$. Usystematyzowane zasady księgowości włoskiej wraz z upowszechnieniem arabskiego zapisu cyfr weszły do kanonu kształcenia kupieckiego w Cesarstwie i w całej ówczesnej Europie ${ }^{57}$; od połowy XVI stulecia uczył się tego każdy ambitniejszy czeladnik kupiecki. Chociaż w różny sposób aplikowano te metody do miejscowych praktyk prawno-urzędowych, to pośmiertne inwentarze mienia spisywane $\mathrm{w}$ różnych regionach są do siebie znacząco podobne ${ }^{58}$.

Nowoczesne metody podwójnej buchalterii szybko dotarły do Gdańska ${ }^{59}$ i pozostałych miast Prus Królewskich. Jedną z najważniejszych i najlepszych ówczesnych prac opisujących techniki prowadzenia rachunkowości gospodarczej — podaję za opracowaniem Edwarda Wojciechowskiego $^{60}$ — była książka Sebastina Gamersfeldera, Buchhalten durch zwei Bücher nach italianicher Art und Weise z 1570 r. ${ }^{61}$ Gemersfelder szybko znalazł miejscowych naśladowców i na gdańskim rynku pojawiły się kolejne podręczniki rachunkowości dla młodzieży autorstwa gdańskiego notariusza i rachmistrza, Wolfganga Sartoriusa de Sada z 1592 r. ${ }^{62}$ oraz Ambrosiusa Lerice z 1606 r., zamieszkałego w Gdańsku genueńczyka ${ }^{63}$. W gdańskich zbiorach zachował się nawet sporządzony w 1564 r. odpis nieopublikowanego podręcznika kupieckiego autorstwa Matteusa Schwartza, słynnego księgowego Jakoba Fuggera z Norymbergii ${ }^{64}$. Kolejne prace gdańskich rachmistrzów tylko utrwalały i doskonaliły umiejętności posługiwania się podwójną księgowością ${ }^{65}$ wraz z technikami tworzeniem inwentarzy, aby odwołać się do Paula Hermelinga, Vollkommenes Buchhalten (1685) ${ }^{66} \mathrm{i}$ innych, jak np. praca Johanna Gottfrieda Martzena, General Erklärung des so genannten Italiänischen-Kauffamannischen Buchhaltens $(1713)^{67}$. Warto wspomnieć, że nawet w pośmiertnych inwentarzach mienia gdańszczan odnajdujemy wzmianki o posiadanych przez nich podręcznikach podwójnej księgowości ${ }^{68}$.

53 Zob.: Fierz M. 1977; Sojak S., Kowalska M. 2015, s. 155-179.

${ }^{54}$ Christoffels J.Y. 1543.

55 Kock D. 1663. Jest to jedno z późniejszych, dostępnych mi wydań. Wcześniejsze publikacje tego nauczyciela rachunków podaje Hoogendoorn K. 2018, s. 219-225. Omówienie rozwoju księgowości kupieckiej w Holandii, zob.: de Waal P. 1934, s. 1-57; Hagers J. 1903.

${ }^{56}$ Snell Ch. 1701. Zob. różne przykłady recepcji tych podręczników rachunkowych w Holandii i Anglii w XVI w. zebrane w: Vine A. 2019, s. 151-153.

57 Penndorf B. 1933, s. 74-75 (Anglia), s. 76-77 (Niderlandy).

58 Np.: inwentarze kupieckie w Poznaniu (Inwentarze mieszczańskie. 1965), Rewlu (Talinie) (Die Nachlaßinverzeichnisse. 1997) oraz Lubece (Pelus-Kaplan M.-L., Eickholter M. 1993, s. 279-325). Podobnie były sporządzane inwentarze żydowskich imigrantów w Nowym Jorku pod koniec XVIII w. (Hershkowitz L. 1990, s. 21-55).

59 Penndorf B. 1933, s. 99-107; zob.: Pelus-Kaplan M.-L.1994, s. 31-45.

${ }^{60}$ Wojciechowski E. 1956/1957, s. 469-483; artykuł autorstwa trojga autorów (Gierusz J., Keiser A., Połczyńska-Gościniak R. 1999, s. 49-64), jedynie powtarza ustalenia Edwarda Wojciechowskiego oraz Andrzeja Grodka i Izabelli Surmy (Z historii rachunkowości. 1959); zob.: Szychta A. 1989.

${ }^{61}$ Gamersfelder S. 1570. Przegląd gdańskich dokumentów i podręczników kupieckich podał Wojciechowski E. 1957, 439-443, 487-490. Fragmenty gdańskich podręczników przedrukowane w polskim tłumaczeniu w: Z historii rachunkowości. 1959. Dla innych miast ówczesnej Rzeczpospolitej, zob.: Szychta A. 1988, s. 58-68.

62 Sartorius W. 1592.

${ }^{63}$ Lerice A. 1606.

${ }^{64}$ Copia und Abschrift. 1564 (do rękopisu dołączono ekspertyzę wykonaną przez B. Penndorfa z 1911 r.).

65 Szybko znalazła ona zastosowanie w miejskiej księgowości, Pelc J. 1937, s. 22-27.

${ }^{66}$ Hermling P. 1685, s. 61 (8): Wie man im Inventario, Geld, Guth, Hauß, Schuld, und Gegen-Schuld, Debet und Credit stellet.

${ }^{67}$ Martzen J.G. 1713, s. 3-4, 19-20.

${ }^{68} \mathrm{~W}$ inwentarzu niejakiego Anthonego Thiele z 1636 r. odnotowano książkę Schatzkammer Italienischen Buchhalten, AP Gdańsk, sygn. 300, 1/80, s. 30. Niestety lakoniczna wzmianka nie pozwala zorientować się, o jaką konkretnie pozycję chodzi. 
Według tej usystematyzowanej wiedzy spisywano w Gdańsku inwentarze pośmiertne i inne, np. zajętego mienia bankrutów. W dalszym ciągu pojawiały się jeszcze tradycyjne opisy mienia z natury, lecz miały one jedynie charakter wstępny i służyły tymczasowemu zabezpieczeniu majątku przed rozproszeniem. Sporządzane były podług miejsca przechowywania rzeczy, np. pomieszczeniami, skrzyniami, szafami etc. jak choćby inwentarz po zamordowanych w styczniu 1593 r. mistrzu murarskim Christofie Schultzu i jego żonie Annie ${ }^{69}$. Dysponuję również przykładami z późniejszych czasów ${ }^{70}$. Chociaż stanowią one bardzo przydatne źródło dla rekonstrukcji układu dawnych wnętrz mieszkalnych, to nie miały większego znaczenia praktycznego w postępowaniu spadkowym. Dlatego z reguły mamy do czynienia z inwentarzami tworzonymi wedle charakterystycznych, stosunkowo jednolitych kryteriów rzeczowych ${ }^{71}$, bez oszacowania wartości przedmiotów, lecz zwykle ze skrupulatną kalkulacją cen poszczególnych pozycji ${ }^{72}$. Tak sporządzonym inwentarzom towarzyszą zwykle końcowe rachunki wyprzedaży dóbr wraz z przedstawieniem bilansu końcowego, czyli wyliczeniem masy netto spadku.

Przez lata wypracowany tryb postępowania wszczynano wraz z otrzymaniem informacji o zgonie. Spisy inwentarza domowego wraz z posiadanymi towarami, wyrobami i surowcami (nie znano bowiem rozdziału dóbr prywatnych od majątku przedsiębiorstwa) sporządzano często z inicjatywy samego spadkobiercy, również w porozumieniu z pozostałymi spadkobiercami, ewentualnie wierzycielami. Spisanie majątku mogło również nastąpić po decyzji sądu, który przychylał się do żądania wierzycieli pragnących wyjawienia całego majątku nieboszczyka. Dochodziło do tego w sytuacji, gdy pozostali spadkobiercy lub wierzyciele mieli uzasadnione obawy przed rozproszeniem majątku, próbami jego zatajania, przekazaniem dóbr osobie trzeciej.

Gdy nikt nie chciał się tego podjąć - co mogło się zdarzyć w przypadku śmierci osób przebywających w Gdańsku czasowo (obcy) lub samotnych, gdy głównego spadkobiercy nie znano, nie był obecny w mieście, lub zachodziło podejrzenie, że nie żyje — to spisu dokonywano po decyzji sądu. Urzędnik, np. instigator caducorum, stawał się przymusowym dzierżawcą i właścicielem majątku aż do czasu formalnego zakończenia procedury i ogłoszenia kaduka na rzecz króla lub miasta. W tak dużym mieście jak Gdańsk działała spora grupa dostatecznie dobrze wykształconych urzędników, co przekładało się na bardzo wysoki, niekiedy wzorowy poziom tworzonej dokumentacji procesowej.

W zależności od wielkości masy spadkowej praca komisarzy mogła trwać od kilku chwil (gdy notowano dobytek nędzarza) do wielu tygodni, a nawet miesięcy (jak to bywało z masą spadkową po bogatych kupcach). Dobytek osób ubogich, mieszkających w wynajętej izbie lub podnajmujących kąt do spania u innej, niezbyt zamożnej osoby, spisywano od ręki tego samego dnia, ewentualnie nazajutrz. Po kilku dniach lub tygodniach przystępowano do komisyjnego zinwentaryzowania oraz oszacowania majątków osób zamożniejszych, przede wszystkim mających własne mieszkania lub domy. Ich domostwa lub wybrane pomieszczenia były pieczętowane. Duże majątki wymagały powoływania biegłych rzeczoznawców, którymi byli mistrzowie cechów z danej dziedziny. Zaakceptowany przez strony procesowe inwentarz szacunkowy stanowił podstawę rozliczenia pomiędzy spadkobiercami. Dobra można było sprzedać w drodze licytacji publicznej, lecz główny spadkobierca — po uznaniu wyceny inwentarzowej — mógł zatrzymywać majątek nieruchomy i ruchomy, spłacając lub wydzielając pozostałym sukcesorom rzeczy do wyliczonej wartości ich udziału w spadkobraniu. Gdy byli oni niepełnoletni, niezna-

${ }^{69}$ Inventarium. 1593, k. 28r-34v, 37r-38v; zob. przykład inwentarzowego spisu pomieszczeniami z 1575 r., AP Gdańsk, sygn. 300, 3/9a, k. 27r-30v.

${ }^{70}$ Klonder A. 2000, s. 22; Barylewska-Szymańska E. 2009, s. 188-205; Barylewska-Szymańska B. 2015, s. $14-15$.

${ }^{71}$ Klonder A. 2000, s. 16-21.

72 Przykłady w gdańskich opublikowanych inwentarzach pośmiertnych w: Kizik E. 2000, s. 185-208 (wraz z ujęciem towarów kupieckich); Kizik E. 2002, s. 27-33; Kizik E. 2005, s. 25-31. 
ni lub nieobecni, należna im kwota pieniędzy lub odpowiedni zastaw tej wartości (zwykle w gotówce) był deponowany w sądzie.

Koszty spisania inwentarza oraz innych czynności urzędowych towarzyszących przygotowaniu majątku do spadkobrania, jak również zorganizowanie wyprzedaży, są często ujęte w sumarycznych bilansach zamknięcia jako obciążenie spadku. Wynagrodzenie dla urzędników pochodziło z dwóch źródeł: prywatnego — urzędnicy partycypowali w części opłat administracyjnych uiszczanych przez głównego spadkobiercę (Sterbehaus, Schichtgeber) oraz publicznego - otrzymywali pensję. Ze źródeł z połowy XVII w. wynika, że za przygotowanie spisu majątku o wartości ponad 1400 fl. instygator otrzymał 12 fl., zaś samo sporządzenie inwentarza kosztowało 8 fl. ${ }^{73}$ Z kolei według ordynacji o kadukach z 1 września 1684 r., pracownicy Urzędu Kaduków otrzymywali za pracę przy oszacowaniu do $100 \mathrm{fl}$ - — 9 fl. (czyli nie mniej niż 9\% wartości majątku), do $500 \mathrm{fl}$. — 15 fl. (3\%), zaś od 500 fl. — 25 fl. (maksymalnie do 2,5\% wartości majątku ${ }^{74}$. Kwota była dzielona na trzy części: pomiędzy pisarza, instygatora kaduków oraz posłańców urzędu. Również po ostatecznym przedstawieniu rachunków urzędnicy dostawali do podziału dziesiątą część tej sumy. Ponadto instygator z kasy miejskiej miał wypłacaną jeszcze pensję w wysokości $150 \mathrm{fl}$. rocznie, zaś kursorzy po $50 \mathrm{fl} .^{75}$. Osobno ustalone zostały honoraria dla osób organizujących publiczne wyprzedaże mienia. Według stawek określonych w punkcie 4 ordynacji Rady z 15 maja 1622 r. ${ }^{76}$, licytator za sprzedaż ruchomości zarabiał jeden grosz od każdych 20 gr (tj. grzywny) uzyskanych ze sprzedaży majątku (5\%); współpracujący z nim pisarz otrzymywał pół grosza (2,5\%). Przeprowadzenie licytacji nieruchomości wynagradzano jedną grzywną od 100, zaś pisarz zadawalał się połową tej wartości (1,5\% wartości wylicytowanej). Rewizja ordynacji z 17 sierpnia 1684 r. powtarza ustalenia z początku stulecia ${ }^{77}$. W drugiej połowie XVIII w. wynagrodzenia również uzależnione były od wielkości majątku, którym się zajmowano. Prowizja wynosiła od 1 do 5\% sumy uzyskanej ze sprzedaży. I tak, np. z masy spadkowej po znanym gdańskim malarzu i rytowniku XVIII w. Mathaeusie Deischu (zmarłym 20 stycznia 1789 r.), którą wyprzedano 29 czerwca 1789 r. $^{78}$, licytator potrącił sobie pięcioprocentową zapłatę. Oznaczało to, że ze sprzedaży łącznie 1963 fl. i 23 gr. Ausruffer Samuel Gottlieb Fischer otrzymał za swą pracę 94 fl. i 4 gr; połowę tej sumy zarobił pisarz ${ }^{79}$. Podobnie 5\% (tzn. 79 fl. i 20 gr) pobrał Fischer za zlicytowanie majątku Concordii Bötcher $(1776 \text { r. })^{80}$. Od lichych majątków licytator pobierał wynagrodzenie proporcjonalnie mniejsze. Parę rzeczy po Goffriedzie Mentzlu sprzedano 22 listopada 1773 r. za 26 fl. i 21 gr $^{81}$. Licytator musiał się zadowolić 16 groszami prowizji, co stanowiło $2 \%$ uzyskanej sumy; pisarz dostał 8 gr. Inne czynności administracyjne wyniosły 4 fl. i 24 gr. Po odjęciu kosztów administracyjnych do podziału pomiędzy spadkobierców pozostało 5 fl. i 18 gr.

Uzależnienie zarobku od wysokości kwot uzyskanych w trakcie licytacji przynajmniej teoretycznie dawało gwarancję, że organizator wyprzedaży dołoży starań, by poszczególne przedmioty uzyskały godziwą cenę. Jak najwyższą wyceną zainteresowani byli spadkobiercy, ale również i fiskus, szczególnie, gdy chodziło o przypadające mu kaduki. Niemniej rozporządzenie Rady Miejskiej z 27 marca 1597 r. ${ }^{82}$ nie pozostawia wątpliwości, że nierzadko docho-

73 AP Gdańsk, sygn. 300, 1/80, s. 64.

${ }^{74}$ Caduc Ordnung. 1684.

75 Caduc Ordnung. 1777; Leman [Ch.K.] 1832, s. 353-365.

${ }^{76}$ Ordnung. 1622.

77 Ordnung. 1684.

78 AP Gdańsk, sygn. 300, 1/173, s. 413.

79 AP Gdańsk, sygn. 300, 1/173, s. 472.

${ }^{80}$ AP Gdańsk, sygn. 300, 1/350, s. 109-123.

${ }^{81}$ AP Gdańsk, sygn. 300, 1/340, s. 37.

${ }^{82}$ Rozporządzenie bez tytułu, Bibl. Gd. PAN, Ms 733, s. 93-94. 
dziło do różnych podejrzanych, zgoła oszukańczych praktyk (allerley Unordnung und Unrichtigkeit). Łupem oszustów podających się za powinowatych lub wyznaczonych do kurateli przez denata (so sich vor gute Männer ausgeben) padały zwłaszcza majątki nieletnich, oddanych w kuratelę. 30 lipca 1630 r. rajcy dali wyraz swojemu zaniepokojeniu praktykami, których mieli się dopuszczać opiekunowie majętności osób młodocianych. Otóż okazało się, że opiekunowie, korzystając z pośrednictwa różnych podstawionych osób (jakiś kobiet, służących $\mathrm{i}$ innych), stopniowo (stückweise) rozprzedawali znajomym dobra swoich podopiecznych. Rada zabroniła takich zachowań przypominając, że wszelkie sprzedaże majątku oddanego w opiekę muszą się odbywać przez publiczne aukcje. Jakkolwiek by nie było, poczynania te uznano za szkodliwe na tyle, że Rada zdecydowała o usunięciu wszelkich takich naciągaczy z urzędu zaprzysiężonego licytatora ${ }^{83}$.

Naturalnie, w praktyce każde postępowanie spadkowe różniło się w pewnych szczegółach. Gdańskie źródła dla okresu nowożytnego, szczególnie od schyłku XVI do początku XIX w. zachowały się $\mathrm{w}$ takiej obfitości, że nawet pewne luki w materiale źródłowym nie powinny przeszkodzić dokładnemu opisaniu sposobów alienacji majątku po zmarłych mieszczanach.

Adres Autora:

Prof. dr hab. Edmund Kizik

Instytut Historii

Uniwersytet Gdański

ul. Wita Stwosza 55

80-952 Gdańsk

edmund.kizik@ug.edu.pl

http://orcid.org/0000 000258772025

\section{BIBLIOGRAFIA}

\section{Źródla archiwalne}

AP Gdańsk [Archiwum Państwowe w Gdańsku], Akta miasta Gdańska, Księgi Ławnicze Starego Miasta, 300, 43/172.

AP Gdańsk, Akta miasta Gdańska, Urząd Burgrabiego, sygn. 300, 3/9a.

AP Gdańsk, Akta miasta Gdańska, Urząd Prezydiującego Burmistrza, sygn. 300, 1/80; 168; 173; 335; $340 ; 350$.

AP Gdańsk, Akta miasta Gdańska, Urząd Wiceprezydiującego Burmistrza, sygn. 300, 5/158.

AP Gdańsk, Akta miasta Gdańska, Urząd Wiceprezydiującego Burmistrza, sygn. 300, 5/193e.

Becker Johanan Gottlieb. [ok. 1750]. Disertatio iuridica de testamentis conjugum reciprocis, [ok. 1750], Bibl. Gd. PAN [Biblioteka Gdańska PAN], sygn. Ms 341, k. 2v-20v; [inne odpisy] sygn. Ms 682; Ms 732.

Caduc Ordnung. 1684. Caduc Ordnung, [1 IX 1684], Bibl. Gd. PAN, Ms 733, k. 56r-63r.

Caduc Ordnung. 1777. Eines Rath Caduc Ordnung, [18 VI 1777], AP Gdańsk. Akta miasta Gdańska. Edykty i rozporzadzenia sygn. 300, 93/40.

Copia und Abschrift. 1564. Copia und Abschrift ab und von Mattheus Schwartzen aignen Handtschrift, was das Buchhalten sey [...] 1564, Bibl. Gd. PAN, sygn. Ms. 2297

Der Stadt Dantzigk Willkühren. 1597. Der Stadt Dantzigk Willkühren [...] 1597, AP Gdańsk, Akta miasta Gdańska, Zbiór rękopisów nieurzędowych — Bibliotheca Archivi, sygn. 300, R/X 9.

83 [...] hinführo alle vermeinte Gute Männer, so sich auss eigener Macht des Ambts des geschworner Ausruffer bishero gebrauchet abgeschafft seyn sollen, Bibl. Gd. PAN, Ms 733, s. 94-96. 
Dewitz Johann Heinrich. [po 1746]. Epitaphia und Inscriptiones aller Kirchen der Städte Elbing und deren Territorii [...], AP Gdańsk, Rękopisy Elbląskie, sygn. 492/ 317.

Erörterte successions. 1732. J. H. M., [Johann Heinrich Morgenstern?], Erörterte successions und Erb-Faelle nach den Culmischen und anderen in Dantzig ueblichen Rechten mit Schematibus erläutert, Anno 1732, AP Gdańsk, Akta miasta Gdańska. Zbiór rękopisów nieurzędowych — Bibliotheca Archivi, sygn. 300, R/ T 20.

Erörterte successions. 1727. J. H. M., [Johann Heinrich Morgenstern?]. Erörterte successions und Erb-Faelle nach den Culmischen und anderen in Dantzig ueblichen Rechten mit Schematibus erläutert, Bibl. Gd. PAN, Ms 347 (odpis z 1727 r.), Ms 348 (odpis z 1728 r.).

Inventarium. 1593. Inventarium uber den Verlasenschafft Annen der Mauerschen so den 2ten January zur Nacht von ihrer Magdt Annen ermordett worden undt ihres Mannes Christoff Schultzen, welchen gemeldte Magd [...] bis auf den Todt verwundet hatt, das er den 4. January auch gestorben. [...] Anno 1593, AP Gdańsk, Akta miasta Gdańska. Zbiór rękopisów nieurzędowych — Bibliotheca Archivi, sygn. 300, R/Vv 233, k. 28r-34v, 37r-38v.

Neue Kirchenglocke in Schönbaum. [1744]. Neue Kirchenglocke in Schönbaum, AP Gdańsk, Akta miasta Gdańska, Urząd Mierzei i Szkarpawy, sygn. 300, 2/405.

Neumann Johann Georg. [b.d.], Epitaphia aus der St. Marien oder Münch-Kirche sowie Epitaphia aus der Pfarr- oder St. Nicolai Kirche in Elbing, AP Gdańsk, Rękopisy Elbląskie, sygn. 492/ 971.

Ordnung. 1622. Es Erb. Raths der Stadt Dantzig Ordnung, wie es bey dem Ausruff soll gehalten werden, Bibl. Gd. PAN, sygn. Ms 733.

Ordnung. 1684. Ordnung wornach sich der Ausruffer nebenst seinem Schreiber zuhalten haben, Anno 1684, Bibl. Gd. PAN, sygn. Ms 1079, t. 4, k. 165r-173v.

Rubachs Monathliche Sammlung. [1780-1782]. Rubachs Monathliche Sammlung, Bibl. Gd. PAN, Ms 147.

Schütz Kaspar. 1576. Kurtzer und grundlicher Bericht von Erbfällen (odpis z 1726), AP Gdańsk Akta miasta Gdańska. Zbiór rękopisów nieurzędowych - Bibliotheca Archivi, sygn. 300, R/Aa 14, k. 63-103v. [odpisy z XVII i XVIII w.], sygn. 300, R/T 6a; T 6 ${ }^{\text {b }}$ T 6 ; Vv 50; Vv 53; Vv 55; Vv 78; Vv 97; Vv 154.

\section{Źródla i opracowania publikowane}

Accounting history. 1996. Accounting History from the Renaissance to the Present. Accounting history from the renaissance to the present. Rememberance of Luca Pacioli, red. T.A. Lee, A. Bishop, R.H. Parker, New-York-London 1996.

Barylewska-Szymańska Ewa. 2009, Inwentarze mienia z drugiej połowy XVIII wieku w badaniach nad gdańskimi domami, [w:] Studia i materiały do dziejów domu gdańskiego, red. E. Kizik, cz. 1, Gdańsk, s. 188-205.

Barylewska-Szymańska Ewa. 2015. Od piwnic po strych. Wnętrza domów gdańskich drugiej połowy XVIII wieku, Warszawa-Gdańsk.

Bibliographie zur Geschichte. 2007. Bibliographie zur Geschichte des deutschen Notariats, Zusammengetragen, mit einer Einführung [...] von Wolf-George Harms, Würzburg.

Binerowski Zbigniew. 1963. Gdański przemyst okrętowy od XVII do początku XIX wieku, Gdańsk.

Bogucka Maria. 1962. Gdańsk jako ośrodek produkcyjny w XIV-XVII w., Warszawa.

Cieślak Edmund. 1972. Konflikty polityczne i społeczne w Gdańsku w połowie XVIII w. Sojusz pospólstwa z dworem królewskim, Wrocław.

Die Nachlaßinverzeichnisse. 1997. Die Nachlaßinverzeichnisse der deutschen Kaufleute in Tallin, Bd. 1: 1702-1750, wyd. R. Pullat, Tallinn.

Döring Gustav. 1846. Versuch einer Geschichte und Beschreibung der evangelischen Hauptkirche zu St. Marien in Elbing, Elbing.

Edwards John Richard. 2011, Accounting education in Britain during the early modern period, „Accounting History Review”, vol. 21, 1, s. 37-67.

Ehrenkreutz Stanisław. 1915. O stosunkach majątkowych między matzonkami wedtug prawa chetmińskiego w Warszawie w wieku XVIII, Warszawa.

Fierz Markus. 1977. Girolamo Cardano (1501-1576). Arzt, Naturphilosoph, Mathematiker, Astronom u. Traumdeuter, Basel-Stuttgart. 
Fuchs Michael Gottlieb. 1821-1852, Beschreibung der Stadt Elbing und ihres Gebietes, Bd. 1-3, Elbing.

Gamersfelder Sebastian. 1570. Buchhalten durch zwei Bücher nach italianischer Art und Weise, [Danzig].

Gierusz Jerzy, Keiser Aleksandra, Połczyńska-Gościniak Renata. 1999. Księgowość w Gdańsku w XV i XVI wieku, „Acta Cassubiana”, 1, s. 49-64.

Hagers J. 1903. Bouwstoffen voor de geschiedenis van het boekhouden in de Nederlanden, Rotterdam.

Hanow Michael Christoph. 1745/1767. Ius culmense ex ultima revisione, Danzig, wyd. 2, Danzig.

Hermeling P. 1685. Volkommenes Buchhalten das ist deutliche und eigentliche Anweiss- und Unterrichtung der hochlöblichen Wissenschafft des kauffmänischen Buchhaltens, Danzig.

Hershkowitz Leo. 1990. Asser Levy and the Inventories of Early New York Jews, with Text and Inventory, „American Jewish History”, 80, s. 21-55.

Hoogendoorn Klaas. 2018. Bibliography of the Exact Sciences in the Low Countries from ca. 1470 to the Golden Age (1700), Leiden-Boston.

Inwentarze mieszczańskie. 1965. Inwentarze mieszczańskie z wieku XVIII z ksiag miejskich i grodzkich Poznania, t. 1: (1700-1758), t. 2: (1759-1793), wyd. J. Burszta, Cz. Łuczak, Poznań.

Jus Culmense Correctum. 1711. Jus Culmense Correctum una cum Processus iuris in Dioecesi Varmensi usitato [...], Braunsbergae.

Katalog. 1892. Katalog der Danziger Stadtbibliothek, Bd. 1, Th. 1: Die Danzig betreffenden Handschriften, red. A. Bertling, Danzig.

Kitowski Piotr. 2015. Sukcesja spadkowa w mniejszych miastach województwa pomorskiego w II połowie XVII i XVIII wieku. Studium prawno-historyczne, Warszawa.

Kizik Edmund. 2000. Inwentarz pośmiertny kramarza gdańskiego, mennonity Hendrika van Dührena z 1694 roku, „Almanach Historyczny”, t. 2, s. 185-208.

Kizik Edmund. 2002. Inwentarz pośmiertny gdańskiej mennonitki Cathariny Siemens z 1776 roku, [w:] W kręu badań profesora Wacława Odyńca, red. J. Włodarski, Gdańsk, s. 27-33.

Kizik Edmund. 2003. Gdańskie umowy na odlewanie dzwonów z XVII i XVIII wieku. Uwagi po lekturze pracy Elżbiety Wróblewskiej, „Kwartalnik Historii Kultury Materialnej”, R. L, z. 3-4, s. $405-414$.

Kizik Edmund. 2004. Prawo kaduka w Gdańsku w XVI-XVIII wieku, „Kwartalnik Historii Kultury Materialnej, R. LII, z. 1, s. 5-14.

Kizik Edmund. 2005. Inwentarz pośmiertny gdańskiego rytownika Mattaeusa Deischa, [w:] Portret ponad wszystko. Jacob Wessel i jego wiek. Sztuka Gdańska XVIII wieku, red. A. Mosingiewicz, D. Kaczor, Gdańsk, s. 25-31.

Kizik Edmund. 2009. Kary za bezżeństwo w Gdańsku nowożytnym (w drugiej połowie XVII $i$ na początku XVIII wieku), [w:] Miłość w czasach dawnych, red. B. Możejko, A. Paner, Gdańsk, s. $147-155$.

Kizik Edmund. 2010. Zabezpieczenie finansowe wdów w Gdańsku w XVII-XVIII wieku, „Kwartalnik Historii Kultury Materialnej”, R. LVIII, z. 1, s. 85-98.

Kizik Edmund. 2015. Rękopiśmienna gazeta „,Danziger Monathliche Sammlung” (1773-1792) —źródło do badań nad kultura życia w Gdańsku u schytku XVIII wieku, „Czasy Nowożytne”, 28, s. $129-144$.

Klonder Andrzej. 2000. Wszystka spuścizna w Bogu spoczywającego. Majątek ruchomy zwyktych mieszkańców Elblaga i Gdańska w XVII wieku, Warszawa.

Kock David. 1663. De luchtende Fackel van het Italiaens Boeck-houden, Amsterdam.

Kotarski Edmund. 2000. Fundacje stypendialne w dawnym Gdańsku, [w:] Fundacje i fundatorzy w średniowieczu i epoce nowożytnej, red. E. Opaliński, T. Wiślicz, Warszawa, s. 101-129.

Kropidłowski Zdzisław. 1992. Formy opieki nad ubogimi w Gdańsku od XVI do XVIII wieku, Gdańsk.

Kubicki Rafał. 2010. Kultura materialna w testamentach elblaskich w XV-poczatku XVI w., „Kwartalnik Historii Kultury Materialnej”, R. LVIII, nr 2, s. 199-213.

Kubicki Rafał. 2018. Testamenty mieszkańców Elbląga z drugiej połowy XV w., „Rocznik Elbląski”, R. 28, s. 37-50. 
Kuszewic Paweł. 1623. Prawa chetmińskiego poprawionego [...] xiag pięciorga, Poznań.

Leman [Christian Karl]. 1832. Provinzialrecht der Provinz Westpreußen, Bd. III: Die Statutarrecht der Stadt Danzig, Leipzig.

Lerice Ambrosius. 1606. Eine schöne Forma des Buchhaltens nach rechter italianisch Arth unnd Weise, künstlich zusammen verfasset unnd gesellt auff den preuschen Handel, Dantzig.

Löschin Gotthilf. 1837. Aus alten Testamentesstiftungen und Schenkungs-Akten, [w:] Beiträge zur Geschichte Danzigs und seiner Umgebungen, H. 3, Danzig, s. 39-41.

Maciejewski Tadeusz. 1989. Zbiory wilkierzy w miastach państwa zakonnego do 1454 r. i Prus Królewskich lokowanych na prawie chetmińskim, Gdańsk.

Mannheims Hildegard. 1991. Wie wird ein Inventar erstellt? Rechtskommentare als Quelle der Volksundlichen Forschung, Münster.

Martzen Johann Gottfried. 1713. Gründlicher Unterricht und general Erklärung des so genannten italiänischen-kauffamännischen Buchhaltens, Danzig.

Możejko Beata. 2004. Gdański mieszczanin w obliczu śmierci. Zapisy testamentowe z II połowy XV w. (na podstawie księgi ławniczej), [w:] Mieszczanie, wasale, zakonnicy. Studia z dziejów średniowiecza, red. B. Śliwiński, Malbork, s. 127-162.

Neu-revidirte Willkühr. 1761. Neu-revidirte Willkühr der Stadt Danzig, aus Schluß Sämtlicher Ordnungen, publicirt Anno 1761, Danzig.

Pacioli Luca. 1994. Trattato di partita doppia, Venezia 1494, wyd. A. Conterio, B. Yamey, G. Belloni, Venezia.

Pacioli Luca. 2007. Tractatus XI de Computis et Scriptutis. Summa de Arithmetica, Geometria, Proportioni et Proportionalita, thum. R. Sadowski, K. Dereszowska, K. Mydlarz, Warszawa.

Pelc Julian. 1937. Ceny w Gdańsku w XVI i XVII wieku, Lwów.

Pelus-Kaplan Marie-Louise, Eickholter Manfred. 1993. Lübecker Inventare des 16.-18.Jahrhunderts und ihre rechtliche Grundlage. Chancen und Auswertung, [w:] Wege zur Erforschung städtischer Häuser und Höfe. Beiträge zur fächerübergreifenden Zusammenarbeit am Beispiel Lübeck im Spätmittelalter und in der frühen Neuzeit, Bd. 1, red. R. Hammel-Kiesow, Neumünster, s. 279-325.

Pelus-Kaplan Marie-Louise. 1994. Zu einer Geschichte der Buchhaltung im hansischen Bereich: die Handelsbücher der Lübecker Kaufleute vom Anfang des 16. bis zum Ende des 17. Jahrhunderts, „Zeitschrift des Vereins für lübeckische Geschichte und Altertumskunde”, 74, s. 31-45.

Penndorf Baldiun. 1933. Die Italienische Buchhaltung im 14. und 15. Jahrhundert und Paciolis Leben und Werk, Stuttgart.

Penndorf Balduin. 1913. Geschichte der Buchhaltung in Deutschland, Leipzig.

Peragallo Edward. 1938. Origin and evolution of double entry Bookeeping. A study of italian practica from the fourteenth $c$., New York.

Prawo starochełmińskie. 1985. Prawo starochetmińskie 1584 (1394), wyd. W. Meisel, Z. Zdrójkowski, tłum. A. Bzdęga, A. Gaca, Toruń.

Rewizja lidzbarska. 1997. Rewizja lidzbarska prawa chetmińskiego 1566 (1711), wyd. i thum. A. Groth, Koszalin.

Rewizja nowomiejska. 1993. Rewizja nowomiejska prawa chetmińskiego 1580 (1814) zwana także Jus Culmense Emendatum lub Jus Culmense Polonicum, thum. I. Malinowska-Kwiatkowska, J.Sondel, Torun.

Sangster Alan. 2007. The printing of Pacioli's Summa in 1494: how many copies were printed?, „Accounting Historians Journal”, vol. 34, 1 (June), s. 125-145.

Sartorius Wolfgang. 1592. Buchhalten mit zwey Büchern nach preußischer Müntze Mass und Gewichte, [Danzig].

Sartorius Wolfgang. 1592a. Ein new künstlich Rechenbüchlein auff der Linien und Feder mit viel nützlichen Regeln und Exempeln auff allerley Kauffmannschaft, [Danzig].

Scheffs Marceli. 1939. Z historii księgowości (Luca Pacioli), Poznań.

Simson Paul. 1904. Geschichte der Danziger Willkür, Danzig.

Snell Charles. 1701. Rules for Book-Keeping according to the Italian Manner, London. 
Sojak Sławomir, Monika Kowalska. 2015. Z historii rachunkowości. Księgowość podwójna według Pacioliego i jego włoskich naśladowców z XVI i XVII wieku, „Zeszyty Teoretyczne Rachunkowości Stowarzyszenie Księgowych”, t. 81 (137), s. 155-179.

Sondel Janusz. 1994. Pawet Kuszewicz i jego thumaczenie rewizji nowomiejskiej prawa chetmińskiego, [w:] Historia prawa - historia kultur. Księga pamiątkowa ku czci śp. Prof. Witolda Maisla, Kraków, s. 263-289.

Sowina Urszula. 2002. Wdowy i sieroty w świetle prawa w miastach Korony w późnym średniowieczu $i$ wczesnej nowożytności, [w:] Od narodzin do wieku dojrzałego. Dzieci i młodzież w Polsce, cz. 1: od średniowiecza do wieku XVIII, red. M. Dąbrowska, A. Klonder, Warszawa, s. 15-28.

Szychta Anna, 1988. W trzechsetlecie wydania „Rigisches Rechenbuch” Johanna Wolcka, „Zeszyty Teoretyczne Rady Naukowej”, t. 14, s. 58-68.

Szychta Anna. 1989. Bibliograficzne kalendarium rachunkowości w Polsce od XVI do XIX wieku, Warszawa.

Tuchołka-Włodarska Barbara. 1985. Uwagi o działalności warsztatów prowadzonych przez wdowy po gdańskich złotnikach i konwisarzach w końcu XVII i w XVIII w., „Gdańskie Studia Muzealne”, t. 4, s. 103-113.

Turzyński Mikołaj. 2016. Historiografia rachunkowości - ujęcie komparatystyczne, „Studia Oeconomica Posnaniensia", t. 4, nr 11, s. 271-285.

Verzeichnis. 1903. Verzeichnis der in Danzig bestehenden Stiftungen, Wohltätigkeitsanstalten und gemeinnützigen Vereine. Nach dem Stande am Schlusse des Jahres 1902 [...], Danzig.

Vine Agnes. 2019. Miscellaneous Order. Manuscript Culture and the Early Modern Organization of Knowledge, Oxford University Press.

Volckmann Adam. 1654. Neuverbesserte Notariat-Kunst Oder Hand- und Formularbuch, Th. IV, Leipzig.

de Waal Pieter G.A. 1934. De Engelsche vertoling van Jan Impyn's nieuwe instructie (1e helft $16 e$ eeuw), „Economisch Historisch Jaarboek”, 18, s. 1-57.

Willkühr. 1732. Der See- und Handels-Stadt Dantzig Rechte oder Willkühr so in- und ausserhalb Gericht von allen und jeden zu beobachten. Dem Publico zum besten aufgelegt, Dantzig.

Wojciechowski Edward. 1956/1957. Materiały archiwalne, rękopisy i stare druki gdańskie z zakresu księgowości, „Rocznik Gdański”, t. 15/16, s. 469-483.

Wojciechowski Edward. 1957. Materiaty archiwalne, [w:] E. Wojciechowski, Zarys rachunkowości w dawnej Polsce, „Rachunkowość”, nr 10, s. 439-443; nr 11, s. 487-490.

Ympyn Christoffels Jan. 1543. Nieuwe instructie ende bewijs der looffelijcker consten des rekenboecks ende rekeninghe, Antwerp [wydanie faksymile: London-Tokyo 1979].

Z historii rachunkowości. 1959. Z historii rachunkowości w Polsce i Gdańsku w wieku XVI. Wybór tekstów, wyd. A. Grodek, I. Surma, Warszawa.

\section{Reciproce testaments in Gdańsk and the origin of probate inventories in the 17 th-18th $\mathrm{c}$.}

The article focuses on two crucial issues connected with property inheritance in Gdańsk (Danzig) in the 17th-18th c. First, it discusses spouses' reciprocal last wills (reciproce testaments) as a form widely used in this city and its impact on the practice of establishing the net value of the inheritance. Second, it explains the origin of the probate inventory and the popularization of the particular formal characteristics of this document throughout Europe. On the basis of thousands of testaments and probate inventories of Gdańsk burghers from the period between the last quarter of the 16th c. to the early 19th c. surviving in the State Archives in Gdańsk it is possible to analyse in detail how those legal instruments developed in the early-modern era. 
In the light of the Kulm Law (ius culmense, Kulmer Recht), which was applied in Gdańsk, a reciproce testament drawn up by spouses made it possible to enlarge the portion of the inheritance due to the widow (or widower), or to another heir indicated, or to make a charity bequest. This legal instrument allowed to keep up to $7 / 8$ of the worth of the spouses' property and served to protect the integrity of their workshops. The Kulm Law, following the Flemish law, protected the interests of widows, and did not exclude women - widows or daughters - from inheriting, treating them on a par with male heirs. A key issue in inheritance proceedings was the evaluation of property and of its portions due to particular heirs, some of whom were often minors. This required a socially accepted legal instrument, i.e. a reliable official probate inventory, which was the basis of evaluating the property and its portions going to individual heirs.

On the basis of the documents surviving in the State Archives in Gdańsk, and published comparative materials concerning various regions of early-modern Poland and Europe, the author claims that the widespread knowledge of the rules of drawing probate inventory, as well as the characteristic formal features of probate inventories (the subject order, the balance of values) had resulted from adopting the book-keeping techniques developed since the 14th c. by Italian merchants. Theoretical knowledge and practical tips about drawing an inventory and a balance sheet were systematized by Fra Luca Pacioli de Burgo (1445-1514?), a Franciscan and a mathematics professor, in 1494 in Summa de Arithmetica, Geometrica, Proportioni et Proportionalita. In treatise XI (Particularis de computis et scripturis) Pacioli described the Venetian method of drawing up an inventory and of keeping basic account books, also presenting the profit-and- oss account and the balance of accounts, which were the beginnings of the future balance sheet. Thanks to the development of printing, Pacioli's ideas were quickly popularized throughout Europe. One of the best works devoted to book-keeping available in Gdańsk at that time was Sebastian Gamersfelder's Buchhalten durch zwei Bücher nach italianicher Art und Weise (published in 1570). The widely described rules of drawing up a probate inventory and a balance sheet were adopted by Dutch, English and German merchants, as well as book-keeping teachers and notaries all over Europe, who adapted them to local legal and social realities (including the level of literacy and arithmetic skills). This also had an impact on the standardization of probate inventories in the 17th and 18th $\mathrm{c}$.

This article is part of research related to the preparation of a monograph on early-modern probate inventories in Gdańsk.

Proofread by

Izabela Szymańska 